\title{
Conformational and Functional Properties of an Undecapeptide Epitope Fused with the C-Terminal End of the Maltose Binding Protein
}

\author{
Philippe Rondard, ${ }^{\ddagger}$ François Brégégère, $\$$ Anne Lecroisey, ${ }^{\S}$ Muriel Delepierre, ${ }^{\S}$ and Hugues Bedouelle*,‡ \\ Unité de Biochimie Cellulaire and Laboratoire de Résonance Magnétique Nucléaire, CNRS URA 1129, Institut Pasteur, 28 rue \\ du Docteur Roux, 75724 Paris Cedex 15, France
}

Received October 7, 1996; Revised Manuscript Received May 8, $1997^{\circledR}$

\begin{abstract}
Monoclonal antibody mAb164 is directed against the $\operatorname{TrpB} B_{2}$ subunit of the Escherichia coli tryptophan synthase. It recognizes the synthetic peptide P11, constituted of residues 273-283 of TrpB, with high affinity. We constructed a hybrid protein in which the C-terminal end of protein MalE was linked with the N-terminal end of P11. Hybrid MalE-P11 was produced in E. coli from a plasmidic gene and purified in one step as MalE. MalE-P11 and the isolated P11 had identical conformational and functional properties according to the following criteria. The NMR spectra of MalE and MalE-P11 in TOCSY experiments showed that the P11 moiety of MalE-P11 moved independently from its MalE moiety. The chemical shifts of the protons for the P11 moiety of MalE-P11 and for the isolated P11 were very close and did not show significant deviations from random coil values. The equilibrium constant of dissociation $\left(K_{\mathrm{D}}\right)$ from mAb164, measured by a competition ELISA, was identical for MalE-P11 and the isolated P11, around $6 \mathrm{nM}$. The change of the C-terminal residue of MalE-P11 from Lys into Ala increased 37-fold this dissociation constant. This increase showed that the P11 moiety of MalE-P11 was not degraded. The high molecular mass of MalE-P11 allowed us to follow its kinetics of interaction with immobilized mAb164 by surface plasmon resonance, using the BIAcore apparatus. The rates of association with $\mathrm{mAb} 164$ were similar for MalE-P11 and $\operatorname{TrpB}_{2}$, but the dissociation was faster for MalE-P11 than for $\operatorname{TrpB}_{2}$, as previously observed for the isolated $\mathrm{P} 11$ by a fluorometric method. Thus, the fusion of peptides with the C-terminal end of MalE could constitute an alternative to chemical synthesis for the study of their recognition by receptors, in vivo or in vitro.
\end{abstract}

Interactions between peptides and proteins are generally analyzed using chemically synthesized peptides. However, genetic approaches have been developed recently (Van Heeke et al., 1994). In these approaches, the peptide of interest is fused with the N-terminal end of a carrier protein (e.g., the gene III or gene VIII proteins of bacteriophage M13; Scott \& Smith, 1990; Greenwood et al., 1991) or with its C-terminal end (e.g., the glutathione S-transferase, staphylococcal protein A, or streptococcal protein G; Löwenadler et al., 1987; Carter et al., 1994) or inserted within the continuity of the protein (e.g., the maltose binding protein of Escherichia coli, MalE, ${ }^{1}$ or the immunoglobulin $\mathrm{V}_{\mathrm{L}}$ domain REI; Martineau et al., 1992; Zhao et al., 1995). After expression in bacterial cells, the peptide can be either studied in the context of the carrier protein or cleaved from it (Nygren et al., 1994).

Hybrid proteins have several advantages over synthetic peptides. They can give high yields of production at low cost. They can be easily purified by affinity chromatography if the carrier protein has a specific affinity. The passenger

\footnotetext{
* Corresponding author: Tel 33-1-45 68 83 79; fax 33-1-40 6130 43; email hbedouel@pasteur.fr.

$¥$ Unité de Biochimie Cellulaire.

$\S$ Laboratoire de Résonance Magnétique Nucléaire.

${ }^{\otimes}$ Abstract published in Advance ACS Abstracts, July 1, 1997.

${ }^{1}$ Abbreviations: MalE, maltose binding protein, product of the malE gene of Escherichia coli; TrpA and TrpB, subunits of tryptophan synthase, products of the $\operatorname{trp} A$ and $\operatorname{trp} B$ genes of E. coli; $\operatorname{Trp} \mathrm{A}_{2} \operatorname{TrpB}{ }_{2}$, tryptophan synthase; ELISA, enzyme-linked immunosorbent assay; NMR, nuclear magnetic resonance; TOCSY, total correlation spectroscopy; FID, free induction decay.
}

peptide is free of rearrangement byproducts known to occur when synthetic peptides are deblocked or treated at extreme $\mathrm{pH}$. The hybrid protein may be used in a manner similar to synthetic peptides chemically coupled to a carrier protein but with the advantage of reproducibility. Mutations can be introduced into the passenger peptide by oligonucleotide site-directed mutagenesis. Small peptides, from 8 to 20 amino acids in length, are often difficult to crystallize and hybrid proteins can be used as alternate crystallization paths. In many examples, the hybrid protein is used to raise antibodies against the passenger peptide.

MalE, a periplasmic protein of 370 residues, is widely used as a carrier protein (Bedouelle \& Duplay, 1988; Guan et al., 1988). Its main advantage resides in its ease of purification, by affinity chromatography on cross-linked amylose, and the very mild conditions of elution, by competition with free maltose (Kellermann \& Ferenci, 1982). Proteins or protein fragments with very diverse structures and functions have been fused with the N- or C-terminal end of MalE. Both partners of these hybrid proteins, MalE and the passenger protein, remain functional in most cases (Bedouelle \& Duplay, 1988; Blondel \& Bedouelle, 1990, 1991; Brégégère et al., 1994; Blondel et al., 1996; England et al., 1997). Antigenic peptides (e.g., viral epitopes) have been inserted in permissive sites within the sequence of MalE, i.e., sites such that the insertion does not perturb the localization, structure, and activity of MalE (Duplay et al., 1987). The fused peptide is generally immunogenic but its antigenic properties strongly depend on the site of insertion (Martineau et al., 1992; Hofnung \& Charbit, 1993). The precise fusion 


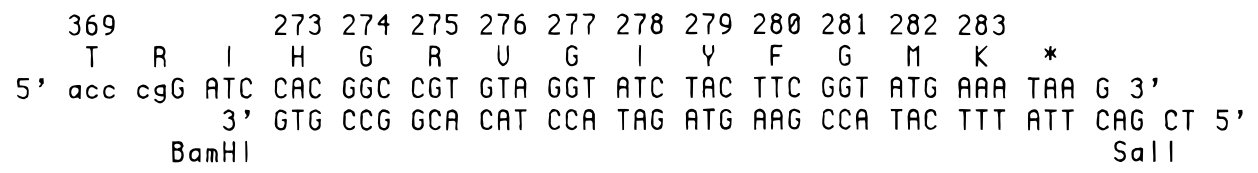

FIGURE 1: Sequence of the malE-p11 gene. The joint between the malE140 allele (lowercase letters) and the $p 11$ gene (uppercase letters) is indicated. malE140 carries a BamHI restriction site inserted into the $3^{\prime}$ terminal codon of malE. This insertion changes the C-terminal residue of MalE from Lys370 into Arg. The residues of P11 are numbered according to their positions in the sequence of TrpB.

of short peptides with the C-terminal end of MalE has not been attempted thus far.

mAb164 is a mouse monoclonal antibody that is directed against the native form of one subunit (the homodimer $\operatorname{TrpB}_{2}$ ) of the tryptophan synthase from E. coli. The equilibrium dissociation constant $\left(K_{\mathrm{D}}\right)$ of their complex is equal to $1 \mathrm{nM}$ (Friguet et al., 1989a). mAb164 recognizes a synthetic peptide, called P11, with a high affinity since its $K_{\mathrm{D}}$ is equal to $7 \mathrm{nM}$. $\mathrm{P} 11$ is constituted of residues 273283 of TrpB (Larvor et al., 1991). We have undertaken a comparison of the structural mechanisms by which antibody mAb164 recognizes the antigenic peptide $\mathrm{P} 11$ and the parental protein $\operatorname{TrpB}_{2}$. In this paper, we describe and validate the genetic approach that we have developed for this purpose. We constructed a hybrid protein, MalE-P11, in which the C-terminal end of MalE was linked with the $\mathrm{N}$-terminal end of P11. We found that MalE-P11 could be produced in E. coli from a plasmidic gene and purified in one step by affinity chromatography on a column of crosslinked amylose, as MalE. We first analyzed whether the fusion with MalE constrained the conformation of P11 by comparing the proton NMR spectra of MalE, P11, and MalE-P11. We used the fact that regions of greater mobility in large proteins can be recognized by NMR dynamic filtering. We then analyzed the recognition between MalEP11 and mAb164 by comparing the $K_{\mathrm{D}} \mathrm{S}$, measured in solution by a competition ELISA, for MalE-P11, the isolated $\mathrm{P} 11$, and $\operatorname{TrpB}_{2}$. We also compared the rate constants, measured with the BIAcore apparatus (Pharmacia-Biosensor), for the association and the dissociation between mAb164 and either MalE-P11 or $\operatorname{TrpB}_{2}$. The results showed that P11 had similar conformational and functional properties in its isolated and linked forms. Thus, MalE-P11 and similar hybrids could facilitate the study of the recognition between peptides and their receptors.

\section{MATERIALS AND METHODS}

Strains and Vectors. The E. coli strains HB2200 (malT recAl hsdRl7 hsdM+) (Bedouelle \& Duplay, 1988), HB2151malT ( $\mathrm{F}^{+}$malT) (Martineau et al., 1990), RZ1032 (Hfr dut ung) (Kunkel et al., 1987), and PD28 (AmalE444 malT $^{c} 1$ recA) (Duplay et al., 1984), plasmids pPD1, pPD127 (Duplay et al., 1984), pAB1 (Blondel \& Bedouelle, 1990), and pTZ18R (Mead et al., 1986) and phage M13KO7 (Vieira \& Messing, 1987) have been described.

Construction of the malE-p11 Hybrid Gene. A synthetic gene fragment, $p 11$, coding for peptide P11, was created by hybridization of two complementary oligonucleotides. The oligonucleotides were designed to give a double-stranded DNA fragment with BamHI and SalI cohesive ends at the $5^{\prime}$ and $3^{\prime}$ ends of the sense strand, respectively (Figure 1). The hybridization was performed by heating a reaction mixture containing $1 \mathrm{nmol}$ of each oligonucleotide, $10 \mathrm{mM}$ Tris- $\mathrm{HCl}, \mathrm{pH} 8.0,10 \mathrm{mM} \mathrm{MgCl}_{2}$, and $100 \mathrm{mM} \mathrm{NaCl}$ for 3 min at $95{ }^{\circ} \mathrm{C}$ and then letting it cool to room temperature
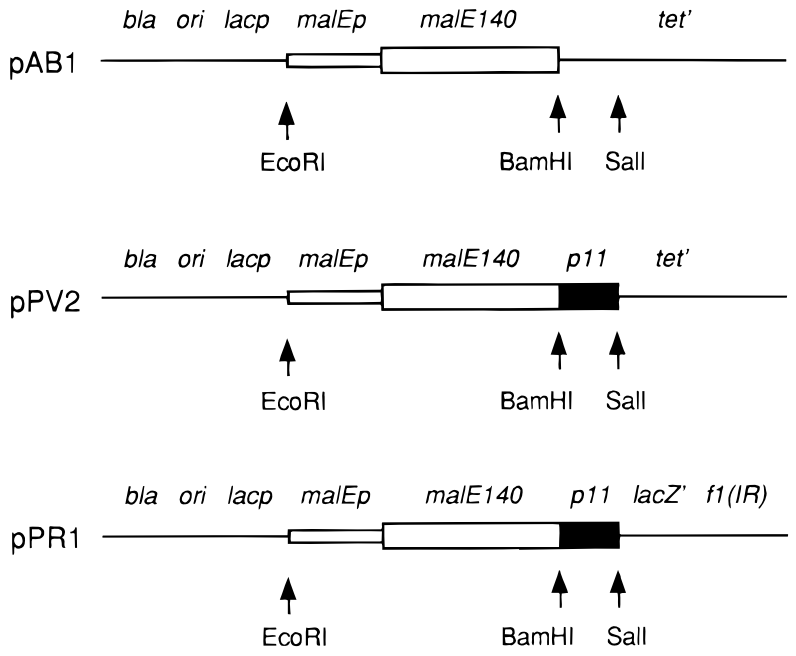

FIGURE 2: Structures of plasmids pAB1, pPV2, and pPR1.

over a period of 3 h. pll was recombined between the BamHI and SalI sites of plasmid pAB1 by ligation (Figure $2)$. The resultant plasmid, pPV2, carried a hybrid gene, malE-p11, between the malE gene and $p 11$, under control of promoter malEp. The EcoRI-SalI fragment of pPV2 that carried malEp and malE-pll was inserted between the EcoRI and SalI sites of phagemid pTZ18R to give pPR1. A mutation of malE-p11 that changed its 3'-terminal codon from AAA (Lys) into GCT (Ala) was created by oligonucleotide site-directed mutagenesis, using the single-stranded DNA of phagemid pPR1 as template (Kunkel et al., 1987). The sequences of the wild-type and mutant malE-pll genes were checked with the T7 sequencing kit (Pharmacia) and the oligonucleotide 5'GGTCGTCAGACTGTCGA3', which hybridizes 35 nucleotides upstream of the $3^{\prime}$ end of malE, as primer. The single-stranded DNA of pPR1 and its mutant derivatives was prepared by using strain HB2151malT as cellular host and phage M13KO7 as helper.

Production, Purification, and Concentration of Proteins. The production of protein MalE from plasmid pPD1 and the productions of the MalE-P11 hybrid proteins from plasmid pPR1 and its mutant derivatives in strain PD28, the preparations of periplasmic extracts and shocked cells by osmotic shock, the purification of MalE and its derivatives by affinity chromatography on cross-linked amylose and elution with maltose (Bedouelle \& Duplay, 1988), and the purification of the $\operatorname{TrpB}_{2}$ subunit and the preparations of its apo and holo forms (Högberg-Raibaud \& Goldberg, 1977) were performed as described previously. Monoclonal antibody mAb164 was produced by injection of hybridoma cells in the peritoneum of mice and purified by chromatography on a DEAEcellulose column as described (Djavadi-Ohaniance et al., 1984; Friguet et al., 1989a).

The concentrations of proteins were calculated from the measures of $A_{280 \mathrm{~nm}}$ and the specific absorption coefficients, $E$. We used the following values, in milliliters per milligram per centimeter: $E\left(\operatorname{TrpB}_{2}\right)=0.58$ (Miles, 1970), $E(\mathrm{mAb} 164)$ 
$=1.5$ (Onoue et al., 1965), $E($ MalE $)=1.47($ Kellerman $\&$ Szmelcman, 1974), $E($ MalE-P11) $=1.46$. To estimate $E(\mathrm{MalE}-\mathrm{P} 11)$, we used the two relationships $e(\mathrm{MalE}-\mathrm{P} 11)$ $=e(\mathrm{MalE})+e(\mathrm{P} 11)$ and $e=E M$, where $e$ is the molar extinction coefficient and $M$ is the molecular mass, with the values $M(\mathrm{MalE})=40707 \mathrm{~g} \cdot \mathrm{mol}^{-1}$ (Duplay et al., 1984), $M(\mathrm{MalE}-\mathrm{P} 11)=42067 \mathrm{~g} \cdot \mathrm{mol}^{-1}$, and $e(\mathrm{P} 11)=e(\mathrm{Tyr})=$ $1420 \mathrm{~L} \cdot \mathrm{mol}^{-1} \cdot \mathrm{cm}^{-1}$ at neutral $\mathrm{pH}$ (Creighton, 1993) since P11 contained only one tyrosine as a chromophore.

Polyacrylamide Gel Electrophoresis and Western Experiments. The protein preparations were analysed by electrophoresis through $10 \%$ polyacrylamide/0.1\% SDS gels and stained with Coomassie blue. The ratio acrylamide/bisacrylamide was 19:1. The Western experiments were performed by electrotransfer of the proteins from polyacrylamide gels to nitrocellulose membranes as described (Sambrook et al., 1989). The proteins were revealed with a rabbit antiserum (Brégégère et al., 1994) or antibody mAb164. Staining was performed with immunoglobulins conjugated with alkaline phosphatase and directed against either the rabbit or mouse IgGs.

NMR Experiments. MalE and MalE-P11 were precipitated from their purified preparations with ammonium sulfate at $80 \%$ saturation. They were recovered by centrifugation, exhaustively dialyzed against water, and freeze-dried. The proteins (about $10 \mathrm{mg}$ ) were dissolved in $650 \mu \mathrm{L}$ of either $\mathrm{H}_{2} \mathrm{O} / \mathrm{D}_{2} \mathrm{O}(9: 1 \mathrm{v} / \mathrm{v})$ or $99.96 \% \mathrm{D}_{2} \mathrm{O}$ (Euriso-top), $10 \mathrm{mM}$ sodium phosphate, $\mathrm{pH} 6.5$, and $1 \mathrm{mM}$ maltose. The samples in $\mathrm{H}_{2} \mathrm{O} / \mathrm{D}_{2} \mathrm{O}$ were acidified to $\mathrm{pH} 4.8$ with $\mathrm{H}_{3} \mathrm{PO}_{4}$ when needed. The homogeneity of the proteins was checked by electrophoresis through SDS-polyacrylamide gels before and after the NMR experiments.

NMR spectra were recorded on a Varian Unity 500 spectrometer equipped with Sun Sparc computers. TOCSY experiments were carried out with mixing times of 40 and $80 \mathrm{~ms}$, using MLEV17 to produce isotropic mixing (Bax \& Davies, 1985; Griesenger et al., 1988). The resonance of the solvent protons was saturated by selective irradiation during the relaxation delay ( $2 \mathrm{~s}$ ). Data sets were collected in the phase-sensitive mode with the hypercomplex scheme (States et al., 1982). Spectra were recorded with a sweep width of $7000 \mathrm{~Hz}$ in both dimensions and 32 scans $/ t_{1}$ increment. A total of 512 FIDs of 2048 data points were collected in $t_{2}$. Prior to Fourier transformation, the spectra were zero-filled to final matrices of $2048 \times 4096$ points in $t_{1}$ and $t_{2}$, respectively, and the matrices were multiplied by a shifted squared sine bell window function to enhance the resolution.

Rate and Equilibrium Constants. The $K_{\mathrm{D}} \mathrm{s}$ between mAb164 and various antigens were measured by a competition ELISA, as described (Friguet et al., 1989b; Rondard et al., 1997). The measurements were performed at $25^{\circ} \mathrm{C}$ in Tris- $\mathrm{HCl}, \mathrm{pH} 7.5,50 \mathrm{mM} \mathrm{NaCl}, 10 \mathrm{mM}$ maltose, and $0.02 \%$ bovine serum albumin for MalE and its derivatives; they were

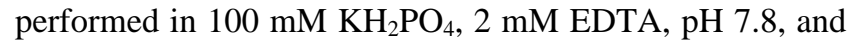
$0.02 \%$ bovine serum albumin for $\operatorname{TrpB}_{2}$ and the synthetic peptide $\mathrm{P} 11$.

The rate constants for association and dissociation were measured with the BIAcore apparatus. mAb164 was covalently immobilized on the carboxymethylated dextran surface of a CM5 sensor chip using the amine coupling kit (Pharmacia-Biosensor). The antigens were diluted in a buffer containing $10 \mathrm{mM}$ phosphate buffer, $\mathrm{pH} 7.4,2.7 \mathrm{mM} \mathrm{KCl}$,
$137 \mathrm{mM} \mathrm{NaCl}, 1 \mathrm{mM}$ maltose, and $0.05 \%$ Tween 20 and passed through the chip at a constant flow of $5 \mu \mathrm{L} / \mathrm{min}$ at $20^{\circ} \mathrm{C}$. After each experiment, the binding sites of mAb164 were regenerated by flushing the chip with $10 \mu \mathrm{L}$ of $15 \mathrm{mM}$ $\mathrm{HCl}$. We used the dissociation constants of $\operatorname{TrpB}_{2}$ into monomers, in its apo and holo forms (Chaffotte \& Goldberg, 1987; Miles, 1991), to calculate the actual molarities of dimers in the BIAcore experiments. These calculated molarities were taken as antigen molarities in the curve fittings.

The kinetic data generated with the BIAcore apparatus were analyzed by a nonlinear least-squares method (O'Shanessy et al., 1993), as implemented in the BIAevaluation 2.1 software (Pharmacia-Biosensor). We fitted the simple exponential function

$$
R=R_{\mathrm{d}} \mathrm{e}^{-k_{\mathrm{off}}\left(t-t_{\mathrm{d}}\right)}
$$

to the profiles of dissociation of the antigens from mAb164, where $R$ is the BIAcore signal (proportional to the surface concentration of protein on the sensor chip), $t$ is time, $t_{\mathrm{d}}$ and $R_{\mathrm{d}}$ are the values of $t$ and $R$ at the start of the measures, and $k_{\text {off }}$ is a fitting parameter. Similarly, we fitted

$$
R=\left(k_{0} / k_{\mathrm{s}}\right)\left[1-\mathrm{e}^{-k_{\mathrm{s}}\left(t-t_{\mathrm{a}}\right)}\right]+R_{\mathrm{a}}
$$

to the profiles of association, where $t_{\mathrm{a}}$ is the start time of the association and $R_{\mathrm{a}}, k_{0}$, and $k_{\mathrm{s}}$ are fitting parameters. The goodness of the fittings was evaluated according to two criteria: a $\chi^{2}$ statistical test and the dispersion of the residual values. In the case of a reversible association between two homogeneous populations of molecules to give a homogeneous binary complex, $k_{\text {off }}$ is the dissociation rate constant of the process, $k_{\mathrm{s}}$ is the apparent association rate constant, and $k_{0}$ is the initial binding rate. $k_{\mathrm{s}}$ and $k_{\text {off }}$ are then linked by

$$
k_{\mathrm{s}}=k_{\mathrm{on}} C+k_{\mathrm{off}}
$$

where $k_{\text {on }}$ is the association rate constant of the process and $C$ is the antigen concentration. Practically, $k_{\text {on }}$ can be determined by fitting a linear function to the related values of $k_{\mathrm{s}}$ and $C$. The equilibrium dissociation constant of the complex between the antigen and the immobilized antibody is then given by

$$
K_{\mathrm{D}}^{\prime}=k_{\mathrm{off}} / k_{\mathrm{on}}
$$

\section{RESULTS}

Construction of the malE-pl1 Hybrid Gene. We constructed the $p 11$ gene, coding for peptide P11, by hybridization of two synthetic complementary oligonucleotides. The resultant double-stranded DNA fragment had BamHI and SalI cohesive ends at the $5^{\prime}$ and $3^{\prime}$ ends of the sense strand, respectively (Figure 1). We assembled the wild-type hybrid gene, malE-pl1 $1^{+}$, by in vitro recombination between the BamHI restriction sites of $m a l E 140$ and $p 11$ (Figure 2). malE140 is a mutant allele of the malE gene that carries a BamHI site in its $3^{\prime}$-terminal codon. We then inserted malE $-p 11^{+}$and its promoter, malEp, into a phagemid vector, pTZ18R. The resultant phagemid, pPR1, coded for a hybrid protein, MalE-P11, composed of residues 1-369 of MalE, a linker of two residues ( $\mathrm{N}$-Arg-Ile-C), and the sequence of 
$\begin{array}{llllllllllllll}1 & 2 & 3 & 4 & 5 & 6 & 7 & 8 & 9 & 10 & 11 & 12 & 13\end{array}$

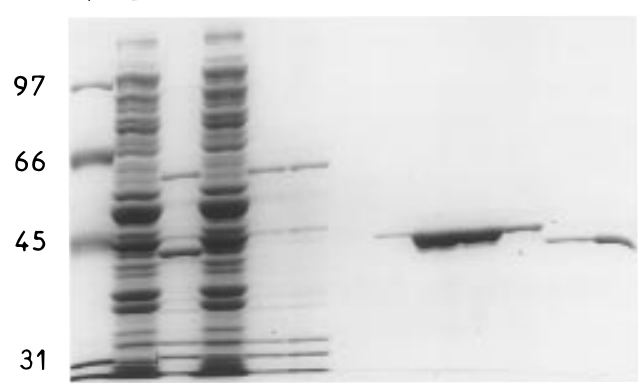

FIGURE 3: Cellular location and purification of MalE-P11. Cellular location: Lanes 2 and 4, shocked cells; lanes 3 and 5, periplasmic extracts; lanes 2 and 3, extracts prepared from PD28(pPR1), producing MalE-P11; lanes 4 and 5, extracts prepared from the control strain PD28(pTZ18R). Protein purification: The periplasmic extract of lane 3 was loaded on a column of crosslinked amylose. Lane 6, flowthrough fraction; lane 7, wash fraction; lanes 8-11, elution of the bound protein with $10 \mathrm{mM}$ maltose. Lane 1, molecular mass markers; lanes 12 and $13, \leq 1 \mu \mathrm{g}$ of purified MalE. The quantity of protein loaded in lanes 2-7 came from $400 \mu \mathrm{L}$ of culture at $A_{600 \mathrm{~nm}}=1.0$.

P11 (N-His-Gly-Arg-Val-Gly-Ile-Tyr-Phe-Gly-Met-Lys-C), for a total of 382 residues. In the following, we will number the residues of $\mathrm{P} 11$ according to their positions in the sequence of TrpB, i.e., His273-Lys283. A mutant derivative, MalE-P11(K283A), in which the C-terminal residue of MalE-P11 was changed from Lys into Ala, was created by site-directed mutagenesis of phagemid pPR1.

Production and Cellular Localization of MalE-P11. To avoid toxicity problems, we used strains HB2200 and HB2151malT as cellular hosts for the recombinant plasmids during the genetic constructions. The malT gene and therefore promoter malEp are inactive in these two strains. To produce hybrid MalE-P11, we transferred phagemid pPR1 into strain PD28, which constitutively expresses the maltose regulon and carries a complete deletion of the malE gene. To determine whether MalE-P11 was produced and what was its cellular location, we submitted cultures of strain PD28(pPR1) to a cold osmotic shock. We analyzed the content of the periplasmic extract and of the shocked cells by SDS-polyacrylamide gel electrophoresis. The periplasmic extract contained a protein with an apparent molecular mass close to the theoretical value for MalE-P11, $42.1 \mathrm{kDa}$. This protein was the major species in the periplasm of PD28(pPR1) and was absent from the periplasm of PD28(pTZ18R) (Figure 3, lanes 3 and 5). These results showed that the 42.1 kDa species corresponded to MalE-P11. Most molecules of MalE-P11 were exported to the periplasm (Figure 3, lanes 2 and 3). Similar results were obtained with MalEP11(K283A).

Purification of MalE-P11. We purified hybrid MalEP11 from a periplasmic extract of strain PD28(pPR1) by chromatography on cross-linked amylose (Figure 3, lanes 6-11). We obtained about $7 \mathrm{mg}$ of purified MalE-P11 from $1 \mathrm{~L}$ of culture at $A_{600 \mathrm{~nm}}=1.0$, which corresponded to about 200000 molecules of MalE-P11/producing cell. Most MalE-P11 molecules ( $>95 \%$ ) were retained by the amylose column during its loading and washing (Figure 3, lanes 3, 6, and 7). Thus, most of them had a MalE portion that was active for amylose binding, and P11 did not prevent the recognition of amylose by MalE. The purified preparations were $>95 \%$ homogeneous (Figure 3, lanes 8-11). Identical results were obtained for MalE-P11(K283A).
Conformational State of P11 in MalE-P11. The threedimensional structure of proteins can generally be studied by NMR up to a molecular weight of 20000 , but investigation of larger proteins is hindered by the loss of spectral resolution. The resonances of the protons overlap because of their large number and of their broadening, which is due to the slow overall rotational tumbling of the protein and to the resulting short values of the transverse relaxation time T2. Simple models predict line widths above $50 \mathrm{~Hz}$ for macromolecules with motions on a time scale going from 5 $\times 10^{-8}$ to $1 \times 10^{-6} \mathrm{~s}$ (Jardetzky \& Roberts, 1981). Most of the signals therefore merge into the background. However, if some regions of a macromolecule present individual motions on a much faster time scale $\left(10^{-9}\right.$ to $\left.10^{-8} \mathrm{~s}\right)$, the protons involved have longer values of $T 2$, their resonances narrow (typically to $5-20 \mathrm{~Hz}$ ), and signals emerge from the background. The regions of greater mobility in a large protein can thus be recognized by NMR dynamic filtering and the sequences of the mobile segments can sometimes be reconstituted from the TOCSY spectra of the protein.

No flexible region could be detected in the wild-type MalE, as already reported (Lecroisey et al., 1997). TOCSY spectra of MalE in $\mathrm{H}_{2} \mathrm{O} / \mathrm{D}_{2} \mathrm{O}$ at $\mathrm{pH} 6.5$ showed few crosspeaks and they could hardly be distinguished from the background, especially in the $\mathrm{NH}-\alpha \mathrm{H}$ region. The lack of cross-peaks in this region was not due to an exchange of the amide protons with deuterium since spectra recorded at pH 4.8 were similar. Only a few spin systems could be identified and the corresponding residues did not fit with any continuous sequence in the protein.

The spectra of MalE-P11 showed several changes when compared with the MalE ones (Figure 4). The amide proton signals were also very low in the MalE-P11 spectra, but cross-peaks with significant intensities appeared in their $\alpha \mathrm{H}$, $\beta \mathrm{H}, \gamma \mathrm{H}$, and $\delta \mathrm{H}$ regions and they could be assigned to known spin systems. We unambiguously identified one arginine, one valine, one isoleucine, one methionine, and one lysine. In addition, in the low-field region of the MalE-P11 spectra, we observed three spin systems that corresponded to aromatic side chains and agreed with histidine, tyrosine, and phenylalanine. However, no cross-peak between the $\alpha \mathrm{H}$ and $\beta \mathrm{H}$ protons of these three residues were visible. The only sequence of MalE-P11 that we could reconstitute from these eight residues was the P11 one (HGRVGIYFGMK) if we assumed that each of the three glycines had similar chemical shifts for their two $\alpha$ protons. Such a condition is fulfilled if these three residues are as flexible as their neighbors. Thus, the P11 moiety of MalE-P11 appeared entirely flexible. It is likely that the two residues linking MalE and P11, ArgIle, were not flexible since we could only detect one Arg and one Ile. We observed no unfolding of the MalE moiety of MalE-P11.

The chemical shifts of the protons belonging to the P11 moiety of MalE-P11 were close to the shifts determined for the protons of the isolated $\mathrm{P} 11$ in $\mathrm{H}_{2} \mathrm{O} / \mathrm{D}_{2} \mathrm{O}$ (Table 1), and they did not show significant deviation from random coil values (Wüthrich, 1986; Wishart et al., 1991, 1995).

Recognition of MalE-P11 in Western Blots. We tested the antigenic activity of MalE-P11 in two parallel Western experiments. Periplasmic extracts of strains PD28(pPD1), producing the wild-type MalE, and PD28(pPR1), producing MalE-P11, were electrophoresed through SDS-polyacrylamide gels and transferred to nitrocellulose membranes in 

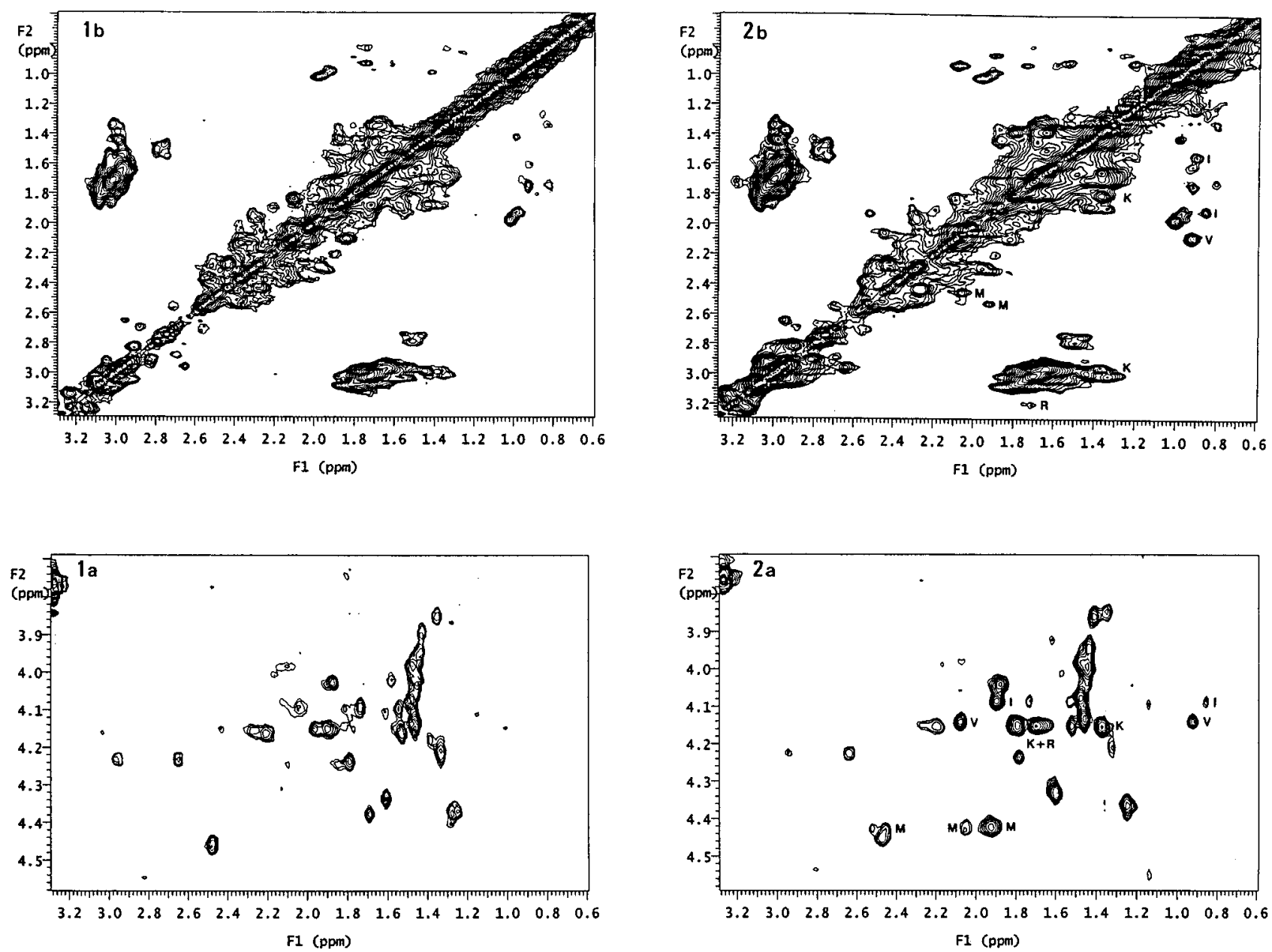

FIGURE 4: Regions of (1) the MalE and (2) the MalE-P11 TOCSY spectra presenting significant differences. (a) $\alpha \mathrm{H}-\beta \mathrm{H}, \alpha \mathrm{H}-\gamma \mathrm{H}$, and $\alpha \mathrm{H}-\delta \mathrm{H}$ regions. (b) $\beta \mathrm{H}-\beta \mathrm{H}, \beta \mathrm{H}-\gamma \mathrm{H}$, and $\beta \mathrm{H}-\delta \mathrm{H}$ regions. Experiments were performed in $\mathrm{D}_{2} \mathrm{O}$ at $35{ }^{\circ} \mathrm{C}$ and $\mathrm{pH} 6.5$ with a mixing time of $60 \mathrm{~ms}$.

duplicate. Purified $\operatorname{TrpB}_{2}$ was used as a control. One membrane was reacted with an anti-MalE serum and the other with mAb164 (Figure 5). The anti-MalE serum recognized MalE (lane 5) and MalE-P11 (lanes 3 and 4) but not $\operatorname{TrpB}_{2}$ (lane 1). mAb164 recognized $\operatorname{TrpB}_{2}$ (lane 6) and MalE-P11 (lanes 8 and 9) but not MalE (lane 10). Only one protein band was revealed by mAb164 or by the antiMalE serum in the periplasmic extract of the strain producing MalE-P11. These experiments showed the following points. mAb164 specifically recognized the P11 moiety of MalE$\mathrm{P} 11$, and the anti-MalE serum recognized its MalE moiety. No protein in a periplasmic extract of PD28(pPR1) reacted with mAb164 or the anti-MalE serum, except the plasmid encoded MalE-P11. No degradation of MalE-P11 could be detected.

Affinity of MalE-P11 for mAb164. We measured the $K_{\mathrm{D}} \mathrm{S}$ between mAb164 and several antigens by a competition ELISA (Table 2). mAb164 had no detectable affinity for the purified protein MalE in these experiments. Moreover, it did not react with the purified MalE in direct ELISA experiments where MalE coated the wells of the microtiter plates. mAb164 had identical $K_{\mathrm{D}}$ values for the isolated P11 and hybrid MalE-P11. Thus, the recognition of P11 by mAb164 was not affected by its fusion with MalE. The $K_{\mathrm{D}}$ for MalE-P11(K283A) was 37 times higher than the $K_{\mathrm{D}}$ for the wild-type MalE-P11. This result showed that the recognition of MalE-P11 by mAb164 was sensitive to the nature of its $\mathrm{C}$-terminal residue. Thus, the $\mathrm{C}$-terminus of
MalE-P11 was not proteolyzed and the purified MalE-P11 was full-length.

Rates of Association with and Dissociation from mAb164. We used the BIAcore apparatus to monitor the kinetics of binding between either MalE-P11 or $\operatorname{TrpB}_{2}$ and immobilized mAb164. We fitted single-exponential functions to the association and dissociation profiles and thus derived the rate constants, $k_{\text {on }}$ and $k_{\text {off. }}$. The ratio $k_{\text {off }} / k_{\text {on }}$ gave the equilibrium dissociation constant, $K_{\mathrm{D}}{ }^{\prime}$, at the interface between the soluble antigen and the immobilized mAb164. $K_{\mathrm{D}}{ }^{\prime}$ is not an equilibrium dissociation constant in solution but yet is useful to compare the binding of different antigens to the same immobilized molecule of antibody (Table 3). We found that MalE-P11 associated 2 times faster than apo-TrpB ${ }_{2}$ with mAb164 but that it dissociated 25 times faster. As a result, the ratio of the $K_{\mathrm{D}}$ 's for MalE-P11 and apo-TrpB 2 was equal to 12 . This ratio was close to the ratio of their $K_{\mathrm{D}} \mathrm{s}$, worth 5.2, determined by competition ELISA.

\section{DISCUSSION}

Comparison between MalE-P11 and P11. Analysis of the isolated P11 by proton NMR has shown that its molecules, in majority, adopt an extended conformation but that some of them, in minority, are structured in their C-terminal part (Delepierre et al., 1991). We found that the chemical shifts of the protons for the isolated P11 and for the P11 moiety of MalE-P11 were very close and did not 
Table 1: Chemical Shifts of the Protons of the P11 Residues in MalE-P11, in the Isolated P11, and in a Random Coil Peptide ${ }^{a}$

\begin{tabular}{|c|c|c|c|c|}
\hline \multirow[b]{2}{*}{ residue } & \multirow[b]{2}{*}{ protons } & \multicolumn{3}{|c|}{ chemical shifts } \\
\hline & & MalE-P11 & P11 & random coil \\
\hline \multirow[t]{3}{*}{ His } & $\alpha \mathrm{H}$ & nd & 3.90 & 4.63 \\
\hline & $\beta \mathrm{H}$ & nd & $3.05,3.00$ & $3.26,3.20$ \\
\hline & $2 \mathrm{H}, 4 \mathrm{H}$ & $7.74,7.00$ & $7.77,7.03$ & $8.12,7.14$ \\
\hline \multirow[t]{4}{*}{$\operatorname{Arg}$} & $\alpha \mathrm{H}$ & 4.15 & 4.37 & 4.38 \\
\hline & $\beta \mathrm{H}$ & 1.70 & 1.75 & $1.89,1.79$ \\
\hline & $\gamma \mathrm{CH}_{2}$ & 1.63 & 1.60 & 1.70 \\
\hline & $\delta \mathrm{CH}_{2}$ & 3.20 & 3.11 & 3.32 \\
\hline \multirow[t]{3}{*}{ Val } & $\alpha \mathrm{H}$ & 4.14 & 4.17 & 4.18 \\
\hline & $\beta \mathrm{H}$ & 2.08 & 2.06 & 2.13 \\
\hline & $\gamma \mathrm{CH}_{3}$ & 0.92 & $0.93,0.92$ & $0.97,0.94$ \\
\hline \multirow[t]{5}{*}{ Ile } & $\alpha H$ & 4.08 & 4.09 & 4.23 \\
\hline & $\beta \mathrm{H}$ & 1.90 & 1.70 & 1.90 \\
\hline & $\gamma \mathrm{CH}_{2}$ & $1.54,1.21$ & $1.20,1.01$ & $1.48,1.19$ \\
\hline & $\gamma \mathrm{CH}_{3}$ & 0.91 & 0.78 & 0.95 \\
\hline & $\delta \mathrm{CH}_{3}$ & 0.85 & 0.70 & 0.89 \\
\hline \multirow{3}{*}{ Tyr } & $\alpha \mathrm{H}$ & nd & 4.60 & 4.60 \\
\hline & $\beta \mathrm{H}$ & nd & $3.00,2.85$ & $3.13,2.92$ \\
\hline & $2,6 \mathrm{H} ; 3,5 \mathrm{H}$ & $7.02,6.77$ & $7.06,6.77$ & $7.15,6.86$ \\
\hline \multirow[t]{4}{*}{ Phe } & $\alpha \mathrm{H}$ & nd & 4.52 & 4.66 \\
\hline & $\beta \mathrm{H}$ & nd & $3.10,2.98$ & $3.22,2.99$ \\
\hline & $2,6 \mathrm{H} ; 3,5 \mathrm{H}$ & $7.19,7.26$ & $7.30,7.33$ & $7.30,7.39$ \\
\hline & $4 \mathrm{H}$ & 7.13 & 7.23 & 7.34 \\
\hline \multirow[t]{4}{*}{ Met } & $\alpha \mathrm{H}$ & 4.43 & 4.44 & 4.52 \\
\hline & $\beta \mathrm{H}$ & $2.06,1.93$ & $2.02,1.97$ & $2.15,2.01$ \\
\hline & $\gamma \mathrm{CH}_{2}$ & $2.52,2.45$ & 2.55 & 2.64 \\
\hline & $\epsilon \mathrm{CH}_{3}$ & nd & 2.10 & 2.13 \\
\hline \multirow[t]{5}{*}{ Lys } & $\alpha \mathrm{H}$ & 4.15 & 4.16 & 4.36 \\
\hline & $\beta \mathrm{H}$ & 1.80 & $1.80,1.68$ & $1.85,1.76$ \\
\hline & $\gamma \mathrm{CH}_{2}$ & 1.37 & $1.41,1.37$ & 1.45 \\
\hline & $\delta \mathrm{CH}_{2}$ & 1.65 & 1.70 & 1.70 \\
\hline & $\epsilon \mathrm{CH}_{2}$ & 2.96 & $2.98,2.95$ & 3.02 \\
\hline
\end{tabular}

${ }^{a}$ The NMR spectra were recorded at $\mathrm{pH} 6.5$ and $35^{\circ} \mathrm{C}$ for MalE$\mathrm{P} 11$ and at $\mathrm{pH} 7.1$ and $25^{\circ} \mathrm{C}$ for the isolated P11. The chemical shifts for a random coil peptide at $\mathrm{pH} 7.0$ and $35^{\circ} \mathrm{C}$ are taken from Wüthrich (1986).

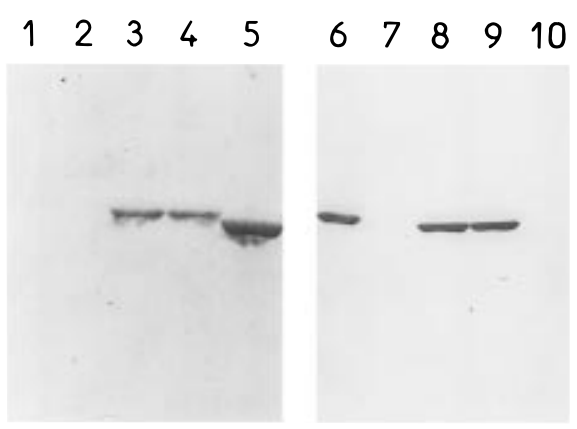

FIGURE 5: Detection of MalE-P11 in a periplasmic extract by Western experiments. The left membrane was revealed with an anti-MalE serum, and the right one with mAb164. Lanes 1 and 6, purified apo-TrpB $\mathrm{B}_{2}$; lanes $2-5$ and $7-10$, periplasmic extracts of PD28 derivatives. Lanes 3, 4, 8, and 9, PD28(pPR1) which coded for MalE-P11; lanes 2 and 7, PD28(pPD127) which coded for a signal peptide mutant of MalE, defective for export; lanes 5 and 10, PD28(pPD1) which coded for MalE.

differ significantly from the values of a random coil peptide (Table 1). Thus, the P11 moiety of MalE-P11 appeared to have the same conformational characteristics as the isolated $\mathrm{P} 11$. We found that mAb164 recognized the isolated P11 and MalE-P11 with identical affinities and that it recognized both of them with weaker affinities than apo- $\operatorname{TrpB}_{2}$ (about 6-fold; Table 2). The kinetics of interaction between soluble molecules of either MalE-P11 or apo-TrpB $\mathrm{B}_{2}$ and immobilized molecules of mAb164, followed with the BIAcore apparatus, showed that MalE-P11 associated only
Table 2: Equilibrium Dissociation Constants at $25^{\circ} \mathrm{C}$ in Solution, Measured by a Competition ELISA ${ }^{a}$

\begin{tabular}{lcc}
\hline \multicolumn{1}{c}{ antigen } & $K_{\mathrm{D}} \pm \mathrm{SE}(\mathrm{M})$ & ratio \\
\hline apo-TrpB 2 & $(1.0 \pm 0.3) \times 10^{-9}$ & 0.2 \\
P11 & $(6.6 \pm 0.8) \times 10^{-9}$ & 1.3 \\
MalE-P11 & $(5.2 \pm 0.8) \times 10^{-9}$ & 1.0 \\
MalE-P11(K283A) & $(1.9 \pm 0.8) \times 10^{-7}$ & 37 \\
\hline
\end{tabular}

${ }^{a}$ The mean value of $K_{\mathrm{D}}$ and the associated standard error from three independent experiments are given. In addition, each ELISA measurement was done in triplicate. The mean $K_{\mathrm{D}}$ value for MalE-P11, 5.2 $\times 10^{-9} \mathrm{M}$, was taken as a reference to calculate the ratio of the $K_{\mathrm{D}} \mathrm{S}$. See Materials and Methods for experimental details.

Table 3: Rate Constants of Association with and Dissociation from Immobilized mAb164 at $20{ }^{\circ} \mathrm{C}^{a}$

\begin{tabular}{cccc}
\hline \multicolumn{1}{c}{ antigen } & $\left\langle k_{\text {off }}\right\rangle\left(10^{-4} \mathrm{~s}^{-1}\right)$ & $k_{\text {on }}\left(10^{4} \mathrm{M}^{-1} \mathrm{~s}^{-1}\right)$ & $K_{\mathrm{D}}{ }^{\prime}\left(10^{-9} \mathrm{M}\right)$ \\
\hline apo-TrpB $_{2}$ & $0.25 \pm 0.02$ & $1.31 \pm 0.23$ & $1.9 \pm 0.5$ \\
holo-TrpB $_{2}$ & $0.50 \pm 0.10$ & $0.62 \pm 0.04$ & $8.1 \pm 2.1$ \\
MalE-P11 & $6.30 \pm 0.12$ & $2.81 \pm 0.13$ & $22.4 \pm 1.5$ \\
\hline
\end{tabular}

${ }^{a}$ The determinations of $k_{\text {off }}, k_{\text {on }}$, and $K_{\mathrm{D}}{ }^{\prime}$ from the BIAcore experimental data are described in Materials and Methods. The concentration of $\operatorname{TrpB}_{2}$ varied between 40 and $400 \mathrm{nM}$, and the concentration of MalE-P11 varied between 24 and $240 \mathrm{nM}$. The values of $k_{\text {on }}$ were determined by fitting eq 3 to the plots of $k_{\mathrm{s}}$ versus the concentration of antigen. Their standard errors in the fitting is indicated. The mean values and standard errors of $k_{\text {off }}$ when the concentration of antigen varied are indicated. The relative errors on $K_{\mathrm{D}}{ }^{\prime}$ were calculated as the sum of the relative errors on $k_{\text {off }}$ and $k_{\text {on }}$.

slightly faster than apo-TrpB 2 (2 times) but dissociated much faster (25 times; Table 3). Compatibly, the kinetics of interaction in solution between either the isolated P11 or $\operatorname{TrpB}_{2}$ and $\mathrm{mAb} 164$, followed by fluorescence spectroscopy, have shown that the isolated P11 associates with the same rate as apo- $\operatorname{TrpB} B_{2}$ but dissociates 5 times faster (Larvor et al., 1991). Thus, P11 had conformational and functional properties very close or identical in MalE-P11 and in its isolated form.

Lack of Interaction between MalE and P11 in Hybrid MalE-P11. The P11 moiety of MalE-P11 appeared entirely flexible in the NMR experiments. Therefore MalE appeared not to constrain the conformation of P11 in the hybrid. Correlatively, the same NMR experiments showed that P11 did not prevent the correct folding of MalE and did not induce the unfolding of its C-terminal part. The P11 moiety of MalE-P11 was fully accessible to mAb164, as shown by the identity of the $K_{\mathrm{D}} \mathrm{s}$ for the isolated P11 and MalE-P11 in competition ELISA experiments. The P11 moiety of MalE-P11 appeared as accessible to mAb164 as residues $273-283$ of $\operatorname{TrpB}$ in subunit $\operatorname{TrpB}_{2}$ since the $k_{\text {on }}$ values for MalE-P11 and $\operatorname{TrpB}_{2}$ were close in the BIAcore experiments. These conclusions are compatible with the fact that the C-terminal helix of MalE (residues 357-370) is located at the surface of the protein and that its $\mathrm{C}$-terminal residue points toward the exterior of the molecule (Spurlino et al., 1991).

Comparison between Insertions and C-Terminal Fusions. The properties of an undecapeptide corresponding to the $\mathrm{C} 3$ epitope of protein VP1 of poliovirus, when it is inserted in 10 different sites within the sequence of MalE, have been reported recently. A proton NMR analysis has shown that the undecapeptide is mostly flexible whatever the site of its insertion is, and that it partially unfolds the flanking regions of the receptor protein in 8 of the 10 cases (Lecroisey et al., 
1997). The affinity of an anti-VP1 monoclonal antibody, measured by competition ELISA, is generally higher for the hybrid protein than for the isolated undecapeptide, but it varies strongly with the site of insertion within MalE (Martineau et al., 1992; Hofnung \& Charbit, 1993). These properties have shown that the regions flanking the site of insertion constrain the conformation of the inserted peptide and affect its antigenic activity. In contrast, the fusion of P11 with the C-terminal end of MalE kept unchanged its conformational and functional properties. Thus, insertion within MalE can be advantageous to constrain a peptide whereas fusion with the C-terminal end of MalE appears advantageous to study the structure-activity relationships of a peptide by site-directed mutagenesis, in conditions very close to those of an isolated synthetic peptide.

MalE as an Added Mass. The kinetics of interaction between a peptide and a receptor are difficult to analyze with apparatus based on surface plasmon resonance, like the BIAcore. The resonance signal is indeed proportional to the density of mass that is bound to the active surface. Therefore, if the receptor is immobilized on the active surface and if the peptide is free in solution, the variation of mass due to the binding of the peptide to the receptor is too small for detection. If the peptide is immobilized on the surface, it is generally not accessible enough to the free receptor. Our results showed that it was possible to increase the molecular mass of a peptide without affecting its properties by fusing it with MalE and, in these conditions, to study its kinetics of interaction with an immobilized receptor using the BIAcore apparatus.

P11 as a Tag. Fusions with peptides have been used to facilitate protein detection and purification (La Vallie \& McCoy, 1995). If the fused peptide is recognized specifically by a monoclonal antibody, its use as a tag eliminates the need to generate an antibody against the protein of interest. Antigenic peptide tags (also called epitope tags) can be used in a variety of applications, including Western experiments, immunoprecipitation, immunofluorescence, and immunoaffinity purification of proteins. Our results showed that P11 could be used as a peptide tag at least in Western experiments and most probably in other immunochemical applications.

Generality of the Results. In this work, we fused the C-terminal end of protein MalE with a short peptide, P11, which comprises 11 residues. We found that the isolated and hybrid forms of P11 had very close conformational and functional properties. In a previous work, we fused the $\mathrm{C}$-terminal end of MalE with a medium-sized peptide, the leucine zipper (Lzp) of the transcriptional activator GCN4 from yeast. Lzp comprises 35 amino acid residues and is responsible for the dimerization of protein GCN4. A synthetic Lzp dimerizes as a coiled coil of two parallel $\alpha$-helices. We have shown that the hybrid between MalE and Lzp is dimeric under conditions where the native MalE is monomeric and that therefore Lzp has similar selfassociation properties when it is in the form of a synthetic peptide, in the form of a hybrid with MalE, or integrated within the native GCN4 (Blondel \& Bedouelle, 1991). In other studies, we have shown that longer proteins or protein fragments generally keep their functional properties when they are fused with MalE (see introduction). Thus, it is likely that peptide P11 is not an exceptional case and that many other peptides and polypeptides will also keep their conformational and functional properties after fusion with MalE.
Perspectives. As mentioned above, the properties of the isolated peptide P11 and of the P11 moiety of hybrid MalE$\mathrm{P} 11$ were very close. MalE-P11 can therefore be used to study the relationships between the structure and activity of P11, in particular to answer questions such as which residues or chemical groups of P11 contribute to its recognition by antibody mAb164 and what is the recognized conformation of P11. To do so, we will construct mutations in the P11 moiety of MalE-P11 at the genetic level, produce the mutant MalE-P11 hybrids in vivo, and purify them by affinity chromatography. We will then compare the $K_{\mathrm{D}} \mathrm{s}$ of the mutant and wild-type MalE-P11 hybrids for mAb164 (Rondard et al., 1997). The genetic and mutational approach that we describe here for P11 and mAb164 could be applied to the study of the recognition between other peptides and their receptors.

\section{ACKNOWLEDGMENT}

We thank Pascale Vignaud for her contribution to an early part of this project, Lisa Djavadi-Ohaniance for the gift of antibody mAb164, and Michel E. Goldberg for his constant interest in this work.

\section{REFERENCES}

Bax, A., \& Davies, D. G. (1985) J. Magn. Reson. 65, 355-360. Bedouelle, H., \& Duplay, P. (1988) Eur. J. Biochem. 171, 541549.

Blondel, A., \& Bedouelle, H. (1990) Eur. J. Biochem. 193, 325330.

Blondel, A., \& Bedouelle, H. (1991) Protein Eng. 4, 457-461.

Blondel, A., Nageotte, R., \& Bedouelle, H. (1996) Protein Eng. 9 , 231-238.

Brégégère, F., Schwartz, J., \& Bedouelle, H. (1994) Protein Eng. 7, 271-280.

Carter, D. C., Rüker, F., Ho, J. X., Lim, K., Keeling, K., Gilliland, G., \& Ji, X. (1994) Protein Pept. Lett. 1, 175-178.

Chaffotte, A., \& Goldberg, M. E. (1987) J. Mol. Biol. 197, 131140.

Creighton, T. E. (1993) Proteins, Structures and Molecular Properties, 2nd ed., p 14, W. H. Freeman and Company, New York.

Delepierre, M., Larvor, M.-P., Baleux, F., \& Goldberg, M. E. (1991) Eur. J. Biochem. 201, 681-693.

Djavadi-Ohaniance, L., Friguet, B., \& Goldberg, M. E. (1984) Biochemistry 23, 97-104.

Duplay, P., Bedouelle, H., Fowler, A. V., Zabin, I., Saurin, W., \& Hofnung, M. (1984) J. Biol. Chem. 259, 10606-10613.

Duplay, P., Szmelcman, S., Bedouelle, H., \& Hofnung, M. (1987) J. Mol. Biol. 194, 663-673.

England, P., Brégégère, F., \& Bedouelle, H. (1997) Biochemistry 36, 164-172.

Friguet, B., Djavadi-Ohaniance, L., \& Goldberg, M. E. (1989a) Res. Immunol. 140, 355-376.

Friguet, B., Djavadi-Ohaniance, L., \& Goldberg, M. E. (1989b) in Protein Structure, A Practical Approach (Creighton, T. E., Ed.) pp 287-310, IRL Press, Oxford, England.

Greenwood, J., Willis, A. E., \& Perham, R. N. (1991) J. Mol. Biol. 220, 821-827.

Griesinger, C., Otting, G., Wüthrich, K., \& Ernst, R. R. (1988) J. Am. Chem. Soc. 110, 7870-7872.

Guan, C. di, Li, P., Riggs, P. D., \& Inouye, H. (1988) Gene 67, 21-30.

Hofnung, M., \& Charbit, A. (1993) in Structure of antigens (Van Regenmortel, M. H. V., Ed.) Vol. I, pp 79-128, CRC Press, Boca Raton, FL.

Högberg-Raibaud, A., \& Goldberg, M. E. (1977) Biochemistry 16, 4014-4020.

Hyde, C. C., Ahmed, S. A., Padlan, E. A., Miles, E. W., \& Davies, D. R. (1988) J. Biol. Chem. 263, 17857-17871. 
Jardetzky, O., \& Roberts, G. C. K. (1981) NMR in Molecular Biology, pp 448-492, Academic Press Inc., New York.

Kellerman, O., \& Szmelcman, S. (1974) Eur. J. Biochem. 47, 139149.

Kellermann, O., \& Ferenci, T. (1982) Methods Enzymol. 90, 459463.

Kunkel, T. A., Roberts, J. D., \& Zakour, R. A. (1987) Methods Enzymol. 154, 367-382.

Larvor, M.-P., Djavadi-Ohaniance, L., Friguet, B., Baleux, F., \& Goldberg, M. E. (1991) Mol. Immunol. 28, 523-531.

LaVallie, E. R., \& McCoy, J. M. (1985) Curr. Opin. Struct. Biol. 6, 501-506.

Lecroisey, A., Martineau, P., Hofnung, M., \& Delepierre, M. (1997) J. Biol. Chem. 272, 362-368.

Löwenadler, B., Jansson, B., Paleus, S., Holmgren, E., Nilsson, B., Moks, T., Palm, G., Josephson, S., Philipson, L., \& Uhlen, M. (1987) Gene 58, 87-97.

Martineau, P., Szmelcman, S., Spurlino, J. C., Quiocho, F. A., \& Hofnung, M. (1990) J. Mol. Biol. 214, 337-52.

Martineau, P., Guillet, J. G., Leclerc, C., \& Hofnung, M. (1992) Gene 113, 35-46.

Mead, D. A., Szczena-Skorupa, E., \& Kemper, B. (1986) Protein Eng. 1, 67-74.

Miles, E. W. (1970) J. Biol. Chem. 245, 6016-6025.

Miles, E. W. (1991) Adv. Enzymol. Relat. Areas Mol. Biol. 49, 127186.

Nygren, P. A., Stahl, S., \& Uhlen, M. (1994) Trends Biotechnol. 12, 184-188.

Onoue, K., Yagi, Y., Grossberg, A. L., \& Pressman, D. (1965) Immunochemistry 2, 401-415.
O’Shannessy, D. J., Brigham-Burke, M., Soneson, K. K., Hensley, P., \& Brooks, I. (1993) Anal. Biochem. 212, 457-68.

Rhee, S., Parris, K. D., Ahmed, S. A., Miles, E. W., \& Davies, D. R. (1996) Biochemistry 35, 4211-4221.

Rondard, P., Goldberg, M. E., \& Bedouelle, H. (1997) Biochemistry 36, 8962-8968.

Sambrook, J., Fritsch, E. F., \& Maniatis, T. (1989) Molecular Cloning, A Laboratory Manual. Cold Spring Harbor Laboratory Press, Cold Spring Harbor, NY.

Scott, J. K., \& Smith, G. P. (1990) Science 249, 386-390.

Spurlino, J. C., Lu, G. Y., \& Quiocho, F. A. (1991) J. Biol. Chem. 266, 5202-5219.

States, D. J., Haberkorn, R. A., \& Ruben, D. J. (1982) J. Magn. Reson. 48, 286-292.

Stevens, F. (1987) Mol. Immunol. 24, 1055-1060.

Van Heeke, G., Stout, J. S., \& Wagner, F. W. (1994) Methods Mol. Biol. 36, 245-260.

Vieira, J., \& Messing, J. (1987) Methods Enzymol. 153, 3-11.

Wishart, D. S., Sykes, B. D., \& Richard, F. M. (1991) J. Mol. Biol. 222, 311-333.

Wishart, D. S., Bigam, C. G., Holm, A., Hodges, R. S., \& Sykes, B. D. (1995) J. Biomol. NMR 5, 67-81.

Wüthrich, K. (1986) NMR of Proteins and Nucleic Acids, Wiley and Sons Inc., New York.

Zhao, B., Helms, L. R., DesJarlais, R. L., Abdel-Meguid, S. S., \& Wetzel, R. (1995) Nat. Struct. Biol. 2, 1131-1137.

BI962508D 